Article

\title{
Performance of Push-Pull Technology in Low-Fertility Soils under Conventional and Conservation Agriculture Farming Systems in Malawi
}

\author{
Saliou Niassy ${ }^{1, *(\mathbb{D})}$, Mawufe Komi Agbodzavu ${ }^{1,2}{ }^{\mathbb{D}}$, Bester Tawona Mudereri ${ }^{1}{ }^{\mathbb{D}}$, Donwell Kamalongo ${ }^{3}$, \\ Ivy Ligowe ${ }^{3}$, Girma Hailu ${ }^{1}$, Emily Kimathi ${ }^{1}$, Zwide Jere ${ }^{4}$, Nathan Ochatum ${ }^{1}$, Jimmy Pittchar ${ }^{1}$, \\ Menale Kassie ${ }^{1}$ (D) and Zeyaur Khan ${ }^{1}$
}

check for updates

Citation: Niassy, S.; Agbodzavu, M.K.; Mudereri, B.T.; Kamalongo, D.; Ligowe, I.; Hailu, G.; Kimathi, E.; Jere, Z.; Ochatum, N.; Pittchar, J.; et al. Performance of Push-Pull Technology in Low-Fertility Soils under Conventional and Conservation Agriculture Farming Systems in Malawi. Sustainability 2022, 14, 2162. https://doi.org/ $10.3390 /$ su14042162

Academic Editor:

Anastasios Michailidis

Received: 28 December 2021

Accepted: 3 February 2022

Published: 14 February 2022

Publisher's Note: MDPI stays neutral with regard to jurisdictional claims in published maps and institutional affiliations.

Copyright: (C) 2022 by the authors. Licensee MDPI, Basel, Switzerland. This article is an open access article distributed under the terms and conditions of the Creative Commons Attribution (CC BY) license (https:// creativecommons.org/licenses/by/ $4.0 /)$.
1 International Centre of Insect Physiology and Ecology (ICIPE), Nairobi P.O. Box 30772-00100, Kenya; m.agbodzavu@cgiar.org (M.K.A.); bmudereri@icipe.org (B.T.M.); ghailu@icipe.org (G.H.); ekimathi@icipe.org (E.K.); nathela2010@gmail.com (N.O.); jpittchar@icipe.org (J.P.); mkassie@icipe.org (M.K.); zkhan@icipe.org (Z.K.)

2 International Institute of Tropical Agriculture (IITA), Haut-Congo, Gombe, Kinshasa 4163, Congo

3 Department of Agricultural Research Services (DARS), Lilongwe P.O. Box 30779, Malawi; dkamalongo@yahoo.com (D.K.); ivyligowe@gmail.com (I.L.)

4 Total Land Care Malawi, Area 12, Plot 520, Lilongwe P.O. Box 2440, Malawi; zjere@tlcmw.org

* Correspondence: sniassy@icipe.org

\begin{abstract}
Push-pull technology (PPT) is one of the most viable low-cost agroecological practices that reduces the effects of insect pest infestations (e.g., stemborer) and parasitic weeds (e.g., Striga) in croplands. PPT was evaluated in low-fertility soils and two farming practices, minimum-tilled conservation agriculture practice (CA), and conventionally tilled practice $(\mathrm{CP})$, in contrasting agroecological zones at the Chitedze, Mbawa, and Chitala stations in Malawi. Stemborer and Striga infestations were also investigated and the suitability levels of two Desmodium species. Farmers' perceptions of PPT were gathered through a focus group discussion. The performance of PPT varied significantly between treatments, sites, and years on grain yields and the number of cobs that could be assigned to soil attributes. Significant variations were found in the number of exit holes, stemborer damage severity, and the number of Striga-affected plants with severe infestation. In Chitedze, CP recorded significantly shorter maize plants by $14.1,11.6$, and $5.8 \mathrm{~cm}$ than CP-PP, CA, and CA-PP, respectively, in 2016-2017. There were no significant differences in plant height between CP-PP, CA, and CA-PP. Similar results were also found in 2017-2018. Focus group discussions among farmers attested to up to $70 \%$ reductions in Striga weed and stemborer pests under PPT over the two seasons. Farmers who used push-pull technology reported a $45-50 \%$ yield increase. Push-pull was also perceived as a technology that improves soil fertility and controls soil erosion. The study presented the importance of soil physicochemical properties in the performance of the technology, as supported by the high occurrence of Striga asiatica in the country and the low suitability of Greenleaf Desmodium. Results reaffirmed the technology's agronomic benefits in productivity, pest management, plant vigour, and Striga control. The cost of labour was described as a challenge, and research to identify more suitable Desmodium species is needed. The current study suggests the release of the technology in Malawi, emphasizing the inclusion of Desmodium and Brachiaria as animal fodder for the adoption of the technology.
\end{abstract}

Keywords: stemborers; infestation; Desmodium; Brachiaria; Striga; maize; yield

\section{Introduction}

Maize Zea mays L. is the staple crop in Malawi and a major source of carbohydrates for over $80 \%$ of the Malawian population [1]. Approximately $70 \%$ of the land area under cultivation is under maize production each year [2]. Unfortunately, maize production in 
Malawi is severely affected by both biotic and abiotic factors. Among the biotic factors, stemborers and the parasitic weed Striga sp. are the most common, with the lepidopteran stemborers causing huge maize yield losses [3]. The spotted stemborer Chilo partellus Swinhoe (Lepidoptera: Crambidae) and the African stemborer Busseola fusca Fuller (Lepidoptera: Noctuidae) are the two most economically important stemborer pests in maize cultivation [4].

On the other hand, Striga infestation in Malawi is also widespread [5] and is one of the major constraints limiting maize [6]. Striga infestation is severe and affects more than $40 \%$ of the maize-cultivated land [7]. Other important factors limiting maize yields in Malawi include low soil fertility and environmental factors, e.g., poor rainfall, heat, and water stress [8].

In Malawi, synthetic chemical pesticides have been traditionally promoted for pest control [9]. However, chemical control is often not successful because the pests burrow out of reach into the stems and hide in the whorls of the plants [10]. Over-reliance on synthetic pesticides leads to ecological and human hazards [9]. Synthetic pesticides are often unaffordable for most African smallholder farmers [11].

Over the past few years, environment-friendly control methods for stemborers have been promoted, including host-plant resistance [12], biological control [13], and habitat management [14,15]. Conservation agriculture (CA) was introduced into Malawi to address many maize-production constraints, based on the perceived benefits for crop yields, soil organic content storage, weed suppression, reduced soil erosion, improved soil water retention $[16,17]$. However, in the last two decades, Malawi has experienced severe climatic disasters in the form of dry spells, seasonal droughts, intense rainfall, riverine floods, and flash floods with increased frequency, intensity, and magnitude, adversely impacting food security and reducing the benefits of the CA approach [17-19]. Moreover, the recent emergence of the devastating fall armyworm (FAW), Spodoptera frugiperda J. E. Smith (Lepidoptera: Noctuidae), has further exacerbated the challenges in maize production in Malawi, forcing the government to declare a state of emergency due to the significance of the losses. The value of FAW losses as a percentage of agricultural GDP in Malawi is estimated at 0.5 percent [20], which is among the highest percentages in the last decade [21].

One of the most successful and viable low-cost agroecological practices being promoted to help curb the problem of insect pests like stemborers and parasitic weeds such as Striga, and poor soil fertility, is push-pull technology (PPT). PPT involves trapping stemborers on highly attractive border plants (pull), Napier grass Pennisetum purpureum Schumach, or Brachiaria cv Mulato II and driving them away. On the other hand, Desmodium uncinatum Jacq. (Silverleaf) and Desmodium intortum Urb. (Greenleaf), planted between maize rows, repel ovipositing stemborer moths (push) [15,22]. In addition, Desmodium enriches the soil with nitrogen and protects it from erosion as it acts as a cover crop, leading to improved maize yields [23-25]. Concurrently, PPT provides high-value animal fodder from the harvest of the companion crops, facilitating increased milk production and diversification of farmers' income sources [26]. Lately, it has been discovered that climate-adapted PPT effectively controls FAW in maize [24,27].

The success of PPT has been attributed to the stimulo-deterrent action of companion crops, which depends on the soil's physicochemical propertiesq [3]. Thus, the suitability of the Desmodium species depends on various climatic factors such as temperature and soil type [28]. In contrast, the incidence of Striga and other insect pests such as the stemborer and FAW varies according to the agro-ecology zones [29]. These aspects have often been overlooked, yet they are critical for scaling this technology. Moreover, investigating the acceptance and use of the technology is a critical aspect of adoption and scaling. These two components are mainly driven by performance and effort expectancy and influenced by gender, age, and experience [30].

The objectives of this study were (i) to investigate the performance of PPT under current farming practices in various agroecological zones; and (ii) to evaluate the suitability 
of Desmodium species and Striga to guide PPT scaling, and (iii) to understand the socioeconomic drivers that may influence the adoption of the technology.

\section{Materials and Methods}

Field experiments were conducted using on-station research sites in Chitala, Chitedze, and Mbawa under unimodal rainfed conditions for three growing seasons between 2016 and 2019, in different contrasting agro-ecologies. On-farm co-validation activities were conducted in Lilongwe, Salima, Nkhotakota, and Mzimba. Figure 1 shows the four agroecological regions in Malawi considered in this study.

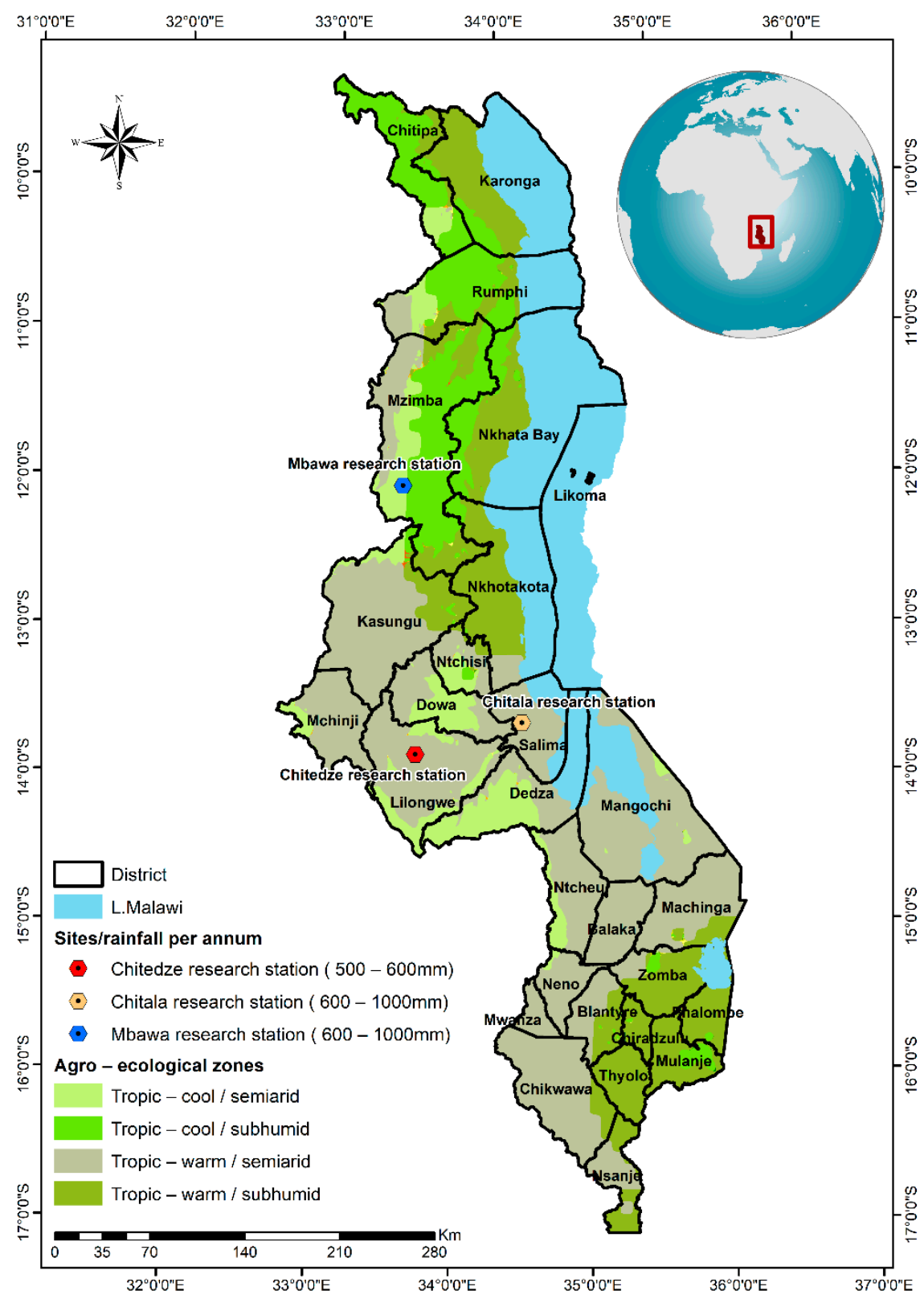

Figure 1. Graphical representation of the four agroecological regions covering the experimental sites in Chitala, Chitedze, and Mbawa research stations.

In Malawi, the rainfall season starts in November-December, which coincides with the planting season of most of the annual crops. The end of the rainfall season is between April and May, which initiates most of the harvesting activities of most crops. Figure 2 shows the rainfall patterns during the three maize growing seasons considered in this study. 


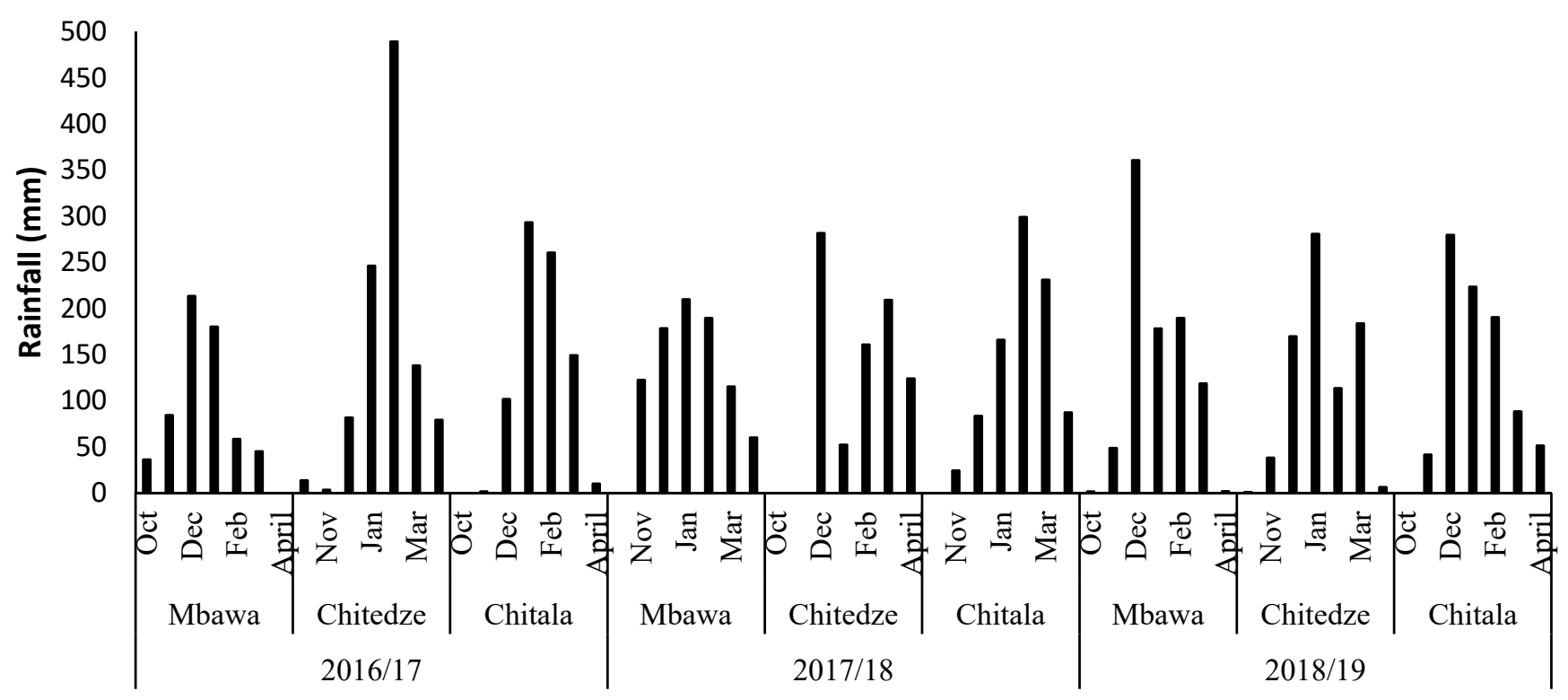

Figure 2. Monthly total rainfall (mm) for the study sites in the 2016-2017, 2017-2018, and 2018-2019 growing seasons in Mbawa, Chitedze, and Chitala, Malawi.

\subsection{Soil Characterisation}

Soil properties are critical for the propagation of Striga and the success of the companion crops in a PPT [31]. The physical and chemical soil properties from the topsoil profile $(0-20 \mathrm{~cm})$ were analysed from the Chitedze Agricultural Research Station laboratory. Soil samples were analysed for total soil organic carbon (SOC) using the Walkley and Black method described by Anderson and Ingrams [32]. Thesoil organic matter (SOM) and mineralisable $\mathrm{N}$ were derived from the SOC and SOM, respectively, by multiplying the percentage concentration with a factor. Phosphorus and exchangeable base cations of $\mathrm{K}$, $\mathrm{Ca}$, and $\mathrm{Mg}$ were analysed using the Mehlich 3 method as described in [33]. The results of the analysis are detailed in Table 1.

\subsection{Design, Treatments, and Field Layout}

A set of four plots or treatments shown in Figure 3 were arranged in a randomised complete block design and replicated three times at every site. The plot size was $10 \mathrm{~m}$ long $\times 10 \mathrm{~m}$ wide, with $0.75 \mathrm{~m}$ between rows. Two of the four plots were sown with maize/Desmodium intercropping under CA (CA-PP) and CP (CP-PP), with grass planted at the perimeter of each plot (Figure 3). A $1 \mathrm{~m}$ buffer separated the plots from each other. The other two plots were sown with maize mono-cropping under $\mathrm{CA}$ and $\mathrm{CP}$. The maize mono-cropping plots were established $5 \mathrm{~m}$ away from the maize/Desmodium intercropping plots (Figure 3). The intercropping treatments and their corresponding monocrops were sown at a similar maize sowing density to compare them. 
Table 1. Physico-chemical soil properties at the end of the growing season.

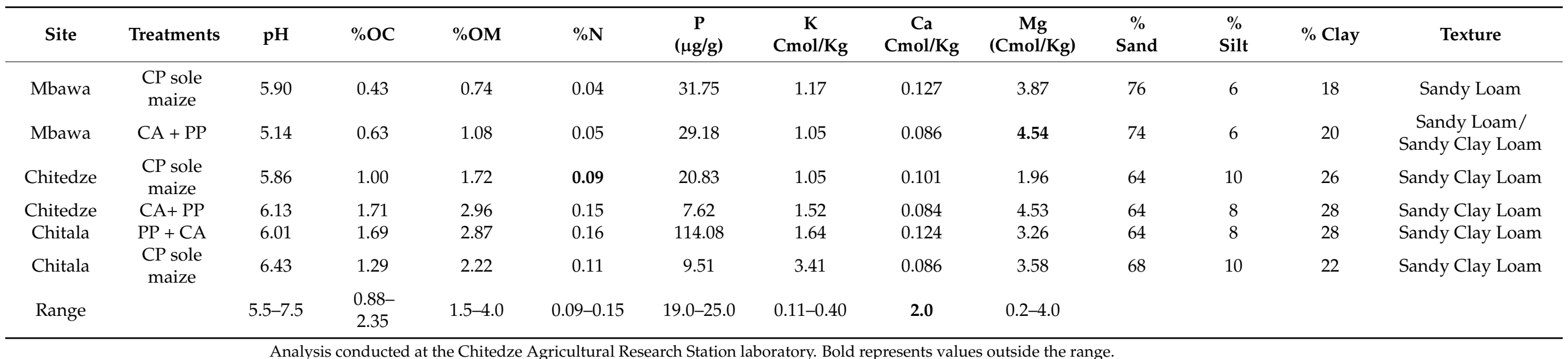



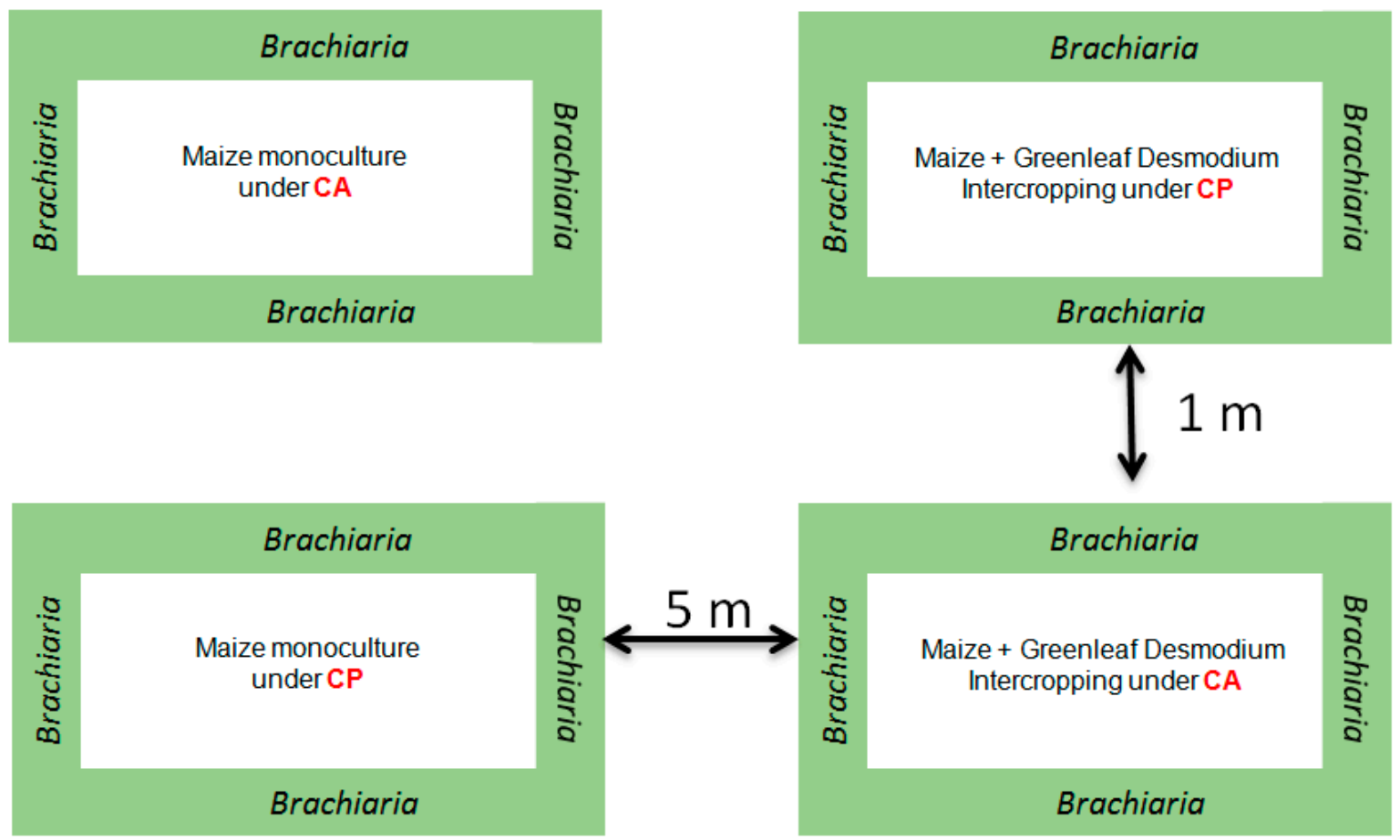

Figure 3. Schematic description of the plot layout. CA: Conservation agriculture; CP: Conventional practice.

\subsection{Land Preparation}

During the first year, the land was ploughed and harrowed in the conventional plots under dry conditions to achieve a fine soil tilth, ensuring good germination of small-seeded legumes such as Desmodium. The untilled CA-based plots were mulched with maize stalks at the recommended 2-3t/ha [34]. The CP-based plots were not mulched to mimic the farmers' CP. In the second and third years, crop residues were removed in the CP plots as per the farmer's practice and retained in the CA plots.

\subsection{Planting and Crop Management}

Maize was used as a test crop and was sown on flat soil surfaces with a dibble stick and ridges in the CA and CP plots, respectively. The rows were spaced at $75 \mathrm{~cm}$ apart, with seeds sown at $25 \mathrm{~cm}$ apart within each row. Two maize seeds were initially sown and later thinned to one plant per planting station, two weeks after emergence, to maintain an optimum plant population of 53,000 per hectare [35]. The same plots and their respective treatments were consistently maintained for three years.

Two rows of Brachiaria were planted around the maize/Desmodium intercropping plots. Desmodium intortum was planted between the two rows of maize in all the intercropping plots at a spacing of $37.5 \mathrm{~cm}$ from the maize row to protect maize from outside Striga infestation (Figure 3). The seeds were mixed with dry sand in the ratio of one part of seeds to three parts of dry sand to ensure the uniform distribution of Desmodium within a row. The seeds were broadcasted into the shallow grooves at an average soil depth of 1 to $2 \mathrm{~cm}$ under adequate soil moisture conditions to enhance good germination [36].

\subsection{Weed Management}

At planting, glyphosate was applied in CA plots at a rate of $2.5 \mathrm{~L} \mathrm{ha}^{-1}$ as a general spray, and careful superficial manual (hand pulling, where necessary light hoe) weeding was performed within the cropping season. Weeding in CP plots was carefully carried out at 3 and 5 weeks after planting (WAP) to avoid uprooting Desmodium intercrop plants. The missing gaps were filled using root splits/cuttings or vines to optimize the Desmodium 
plant population. Desmodium has very aggressive growth habits; if sown as an intercrop and left untrimmed, it can overshadow or smother the maize companion crop. Therefore, Desmodium was continuously trimmed until the maize crop reached knee height before it was left to cover the soil. This activity was performed at 3 and $6 \mathrm{WAP}$, as recommended by Khan et al. [36].

\subsection{Data Collection}

\subsubsection{Maize Yield}

Maize yield data was determined according to an area of $3 \mathrm{~m} \times 3 \mathrm{~m}$ within each plot to avoid border effect errors. The fresh weights of the cobs at harvest were recorded from each quadrant. Composite samples from each treatment (about 5 cobs) were taken for dry cob weight, grain weight, and grain moisture at harvest. Samples were sundried, and grain moisture content was measured and adjusted to $13 \%$ using a handheld grain moisture meter (Dickey-John USA Grain Moisture Tester, Minigac GAC 2500_US, R. K. Enterprises, New Delhi, India) as stipulated in Lark et al. [37]. The grain moisture adjustment was performed to help standardise the yield performance of different treatments and eliminate experimental error sources due to differences in drying methods.

Plant height was recorded at harvest by recording the maize height of 10 plants per plot, from the ground level to the first split of the tassels.

\subsubsection{Striga Infestation and Stemborer Damage}

The Striga experiment was conducted at the Mbawa Research Station in the 2017-2018 and 2018-2019 maize growing seasons. Striga-infested plants were recorded in a $3 \mathrm{~m} \times 3 \mathrm{~m}$ quadrant at 6,8 , and 10 WAP. The scale of 1-4 was used to score the severity of Striga infestation, where 1, 2.5, and 4 meant low, moderate, and high infestations, respectively [38].

The extent of stemborer damage to the maize plants was recorded at the Chitedze Research Station in the 2017-2018 and 2018-2019 maize growing seasons. The severity of the infestation was scored by visual observation of the damage attributed to the pest, using a 1-5 scale at the Mbawa Research Station in the 2017-2018 and 2018-2019 maize growing seasons. According to this prescribed scale, 1 = clean, with no visual infestation symptoms; 2 = very little damage; 3 = high level of damage, where plants show characteristic 'windowpaned' and 'pin-holed' leaves and dead-hearts arising from stemborer larval feeding; $4=$ severe damage, where almost $75 \%$ of the plant is severely affected; and $5=$ very severe damage, where total plant damage due to stem borer is visible $[27,39]$.

\subsubsection{Striga and Desmodium Mapping}

Striga suitability analysis was performed using a GIS multicriteria decision-making approach. A literature review, expert opinions, and information collected in the field guided the variables to be incorporated in the Striga suitability analysis. The variables included annual mean rainfall, annual mean temperature, soil $\mathrm{pH}$, soil organic concentration, and soil nitrogen and sand content. The raster datasets on each of these indicators were assembled, resampled to a resolution of $1 \mathrm{~km}$, and processed from several sources for the Malawi region. The Striga-suitable areas were obtained by overlaying all the thematic layers in terms of weighted overlay methods, using the spatial analysis tool in ArcGIS 10.3 [40].

These layers were reclassified to a common suitability scale of 1 to 9 , where class ' 9 ' represented the highest value. The evaluation scale was chosen following [41]. The reclassified layers were then weighted by assigning an equal percentage influence value. This is achieved by multiplying each raster cell's reclassified value by its layer weight and totaling the values to derive a suitability value. Both weight and rating values were assigned through expert knowledge and field observations. The output was compiled to produce a map indicating Striga suitability levels in Malawi.

In situ data retrieved from the Global Biodiversity Information Facility (GBIF: https: / / www.gbif.org /: accessed 2 November 2021) was used to develop ecological niche models of D. uncinatum (Silverleaf Desmodium) $(n=43)$ and D. intortum (Greenleaf Desmodium) 
$(n=36)$, which are the species favourable for the conventional and climate-smart PPT systems, respectively [27]. Presence records of the two species were combined with 19 bioclimatic variables to assess habitat suitability of the forage legume by using maximum entropy modelling (MaxEnt) in the MaxEnt tool package, version 3.4.0 k, which performs well for modelling presence-only data. This machine learning algorithm estimates a species distribution closest to uniform based on the environmental conditions at known occurrence sites [42]. The 19 bioclimatic layers contain grids of temperature and rainfall variables that interpolate observed data at a spatial resolution of $1 \mathrm{~km}$. The layers were sourced from the Worldclim data repository (https:/ / worldclim.org/: accessed 2 November 2021). The variance inflation factor method was applied to eliminate collinear variables [43]. This exercise was performed using R software's 'usdm' package [44,45]. Out of the 19 bioclimatic variables, 8 were considered for the modelling experiment. Response curves and jack-knife graphs were used to assess variable importance following [43].

Seventy percent of the 'presence only' data was used as training data, while $30 \%$ was used to validate the model $[46,47]$. The threshold independent area under the curve (AUC) of the receiver operating characteristic (ROC) was used to assess the accuracy of the model [48].

\subsection{Focus Group Discussion}

Focus group discussions (FGDs) were used to understand the socio-economic profiles of the targeted villages/communities, the main economic activities, crop and livestock production constraints, and how these constraints are tackled locally [49]. Farmers' perceptions of the technology's benefits and possible adoption challenges were investigated, and an emphasis was placed on maize production constraints. Further, the FGDs elicited information on the sources of agricultural extension information. Eight FGDs were conducted in four of the five project districts (i.e., two FGDs in each district), where PPT was being validated for scaling-up. The four districts covered were Lilongwe, Salima, Nkhotakota, and Mzimba. The FGDs each constituted a group of about 9-25 key informants of both genders. Informants were assembled in a central place in a village. These key informants came from different villages. A prepared checklist was used to guide the discussions, which an economist moderated. An interpreter who was fluent in the local language facilitated the interview. Following the PPT demonstration, the host farmers were asked to enumerate some of the potential benefits they had experienced in the last season when they hosted the demonstrations.

\subsection{Data Analysis}

The data were subjected to the general analysis of variance (ANOVA) model using Genstat (Version 15.1, VSN International Ltd., Hemel Hempstead, UK). Statistical comparisons of the treatment means at a $5 \%$ probability level were conducted using the least significant differences (LSD).

\section{Results}

\subsection{Effect on Grain Yields and Number of Cobs}

Overall, there were significant decreases over the years $(p<0.001)$ and between the various sites $(p<0.001)$, and the interactions between the years and the sites were also significant $(p<0.001)$. Overall, the treatment effect was not significant; however, the interaction between the sites and the treatment was marginally significant $(p=0.045)$. The interaction between treatment and year was not significant, and the combined interaction between treatment, year, and site were also not significant $(p=0.082)$.

\subsection{Effect of Push-Pull Technology on Grain Yields at Chitedze, Mbawa, and Chitala Research Stations}

In Chitedze, the treatments had a significant effect $(p<0.01)$ on the grain yield. In 2016-2017, maize grain yields were significantly higher in CP by 1001, 1967, and $1691 \mathrm{~kg}$ 
than CP-PP, CA, and CA-PP, respectively. The yield in CP-PP was significantly higher by $690 \mathrm{~kg}$ and $966 \mathrm{~kg}$ than those in CA and CA-PP, respectively. In 2017-2018, maize grain yield was significantly higher in CA than CP, CA-PP, and CP-PP by 1031, 1975, and $2761 \mathrm{~kg}$, respectively. There was also a significant difference between $\mathrm{CP}$ on the one hand and CA-PP and CP-PP on the other. In 2018-19, CP treatments again recorded the highest yields, but no significant differences were found between the other treatments.

In Mbawa, there was a significant seasonal effect $(p<0.001)$ on the grain yield. Season 2016-2017 recorded the highest grain yield. In 2016-2017, sole maize treatments in CP and CA had higher grain yields by 2376 and $2316 \mathrm{~kg}$ than in CA-PP. However, no significant differences were found between CA, CP, and CP-PP. In 2017-2018, no significant differences were found between the treatments. In the 2018-2019 season, CP-PP recorded significantly higher maize grain yield by $1227 \mathrm{~kg}$ and $1269 \mathrm{~kg}$ than CA and CP and was not significantly different from CA-PP (Table 2).

Table 2. Effects of treatments on maize grain yield $\left(\mathrm{kg} \mathrm{ha}^{-1}\right)$ research station in the 2016-2017, 2017-2018, and 2018-2019 growing seasons.

\begin{tabular}{|c|c|c|c|c|}
\hline \multicolumn{5}{|c|}{ Growing Seasons } \\
\hline Treatments & 2016-2017 & 2017-2018 & 2018-2019 & $\begin{array}{c}\text { Treatments } \\
\text { Effect }\end{array}$ \\
\hline \multicolumn{5}{|c|}{ Chitedze Research Station } \\
\hline $\mathrm{CA}-\mathrm{PP}$ & $2584^{c}$ & $2229^{c}$ & $3121^{b}$ & 2645 \\
\hline CA sole maize & $2308^{c}$ & $4204^{a}$ & $3811^{b}$ & 3441 \\
\hline $\mathrm{CP}-\mathrm{PP}$ & $3274^{b}$ & $1443^{c}$ & $3457^{b}$ & 2725 \\
\hline CP sole maize & $4275^{\mathrm{a}}$ & $3173^{b}$ & $5260^{a}$ & 4236 \\
\hline Seasonal effects & $3110^{\mathrm{B}}$ & $2762^{\text {B }}$ & $3912^{\mathrm{A}}$ & \\
\hline \multicolumn{5}{|c|}{ LSD Seasons $(Y): 989.1{ }^{*}$ LSD Treatments $(T): 856.6$ ** LSD T $\times$ Y: $1713.2 \mathrm{~ns}$} \\
\hline \multicolumn{5}{|c|}{ Mbawa research station } \\
\hline $\mathrm{CA}-\mathrm{PP}$ & $3300 \mathrm{cbd}$ & $1948^{\mathrm{a}}$ & $3982^{a b}$ & 3077 \\
\hline CA sole maize & $5616^{\mathrm{a}}$ & $2071^{a}$ & $3395 \mathrm{bc}$ & 3694 \\
\hline $\mathrm{CP}-\mathrm{PP}$ & 4859 da & $3046^{\mathrm{a}}$ & $4622^{\mathrm{a}}$ & 4176 \\
\hline CP sole maize & $5676^{\mathrm{a}}$ & $2322^{\mathrm{a}}$ & $3353^{b c}$ & 3784 \\
\hline Seasonal effects & $4863^{\mathrm{A}}$ & $2347^{\text {B }}$ & $3838^{C}$ & \\
\hline \multicolumn{5}{|c|}{ LSD Seasons $(\mathrm{Y}): 1007.4 * * *$ LSD Treatments $(\mathrm{T}): 1163.2 *$ LSD Y $\times$ T: $2014.8 \mathrm{~ns}$} \\
\hline \multicolumn{5}{|c|}{ Chitala research station } \\
\hline $\mathrm{CA}-\mathrm{PP}$ & $8379^{a}$ & $7794^{a}$ & $3299^{a}$ & 6491 \\
\hline CA sole maize & $8569^{a}$ & $6595^{b a}$ & $4384^{a b}$ & 6516 \\
\hline $\mathrm{CP}-\mathrm{PP}$ & 6697 ba & $7009^{a}$ & $3373^{a}$ & 5693 \\
\hline $\mathrm{CP}$ sole maize & $8297^{a}$ & $4320^{\mathrm{cb}}$ & $4135^{\mathrm{a}}$ & 5584 \\
\hline Seasonal effects & $7986^{\mathrm{A}}$ & $6429^{B}$ & $3798^{C}$ & \\
\hline
\end{tabular}

LSD Seasons (Y): $1221.8^{* * *}$, LSD Treatments (T): $1410.8 \mathrm{~ns}, \mathrm{LSD} \mathrm{T} \times \mathrm{Y}: 2343.6 \mathrm{~ns}$

Values with the same letter under the same parameter are not significantly different at ${ }^{*}=p<0.05 ;{ }^{* *}=p<0.01$; $* * *=p<0.001 ; \mathrm{ns}=$ not significant at $p<0.05 ;$ LSD, least significant difference; CA-PP, push-pull system under conservation agriculture (CA) - maize/Desmodium intercropping; CA sole maize, sole maize cropping under CA; $\mathrm{CP}$-PP, push-pull system under $\mathrm{CP}$-maize/Desmodium intercropping; and $\mathrm{CP}$ sole maize, sole maize cropping under CP. Values with letters in the uppercase compare the means across the columns.

In Chitala, there was a significant seasonal effect on the grain yield $(p<0.05)$. No statistical differences were detected between the treatments in 2016-2017 and 2018-2019. However, in 2017-2018 maize grain yields in CP were significantly lower by 3474, 2689, and $2275 \mathrm{~kg}$ than in CA-PP, CP-PP, and CA (Table 2). 
3.3. Effect of Push-Pull Technology on the Number of Maize Cobs at Chitedze, Mbawa and Chitala Research Stations

In Chitedze, there was a significant effect $(p<0.001)$ of the season and the treatments on the number of maize cobs harvested (Table 3). In 2016-2017, CP and CP-PP plots had significantly higher numbers of maize cobs by 11.7, 15.7, and 8.7, 12.7 than CA and CA-PP, respectively. However, in 2017-2018, CP, CA, and CP-PP had a significantly higher number of cobs, respectively, by 12.6, 12.3, and 9.0 than CA-PP. In the 2018-2019 season, CP recorded a significantly higher number of cobs by 4.7,7.7, and 10.0 than CP-PP, CA-PP, and CA (Table 3).

Table 3. Effects of growing seasons and treatments on the mean number of maize cobs harvested (number/plot) between the 2016-2017 and 2018-2019 seasons.

\begin{tabular}{|c|c|c|c|c|}
\hline \multicolumn{5}{|c|}{ Growing Seasons } \\
\hline Treatments & 2016-2017 & 2017-2018 & 2018-2019 & $\begin{array}{c}\text { Treatments } \\
\text { Effect }\end{array}$ \\
\hline \multicolumn{5}{|c|}{ Chitedze Research Station } \\
\hline $\mathrm{CA}-\mathrm{PP}$ & $32.3^{a}$ & $19.7^{b}$ & $28.6^{b}$ & 26.6 \\
\hline CA sole maize & $28.3^{a}$ & $32.0^{\mathrm{a}}$ & $26.3^{b}$ & 28.8 \\
\hline $\mathrm{CP}-\mathrm{PP}$ & $41.0^{\mathrm{b}}$ & $28.7^{\mathrm{a}}$ & $31.6^{\mathrm{b}}$ & 33.7 \\
\hline $\mathrm{CP}$ sole maize & $44.0^{\mathrm{b}}$ & $32.3^{\mathrm{a}}$ & $36.3^{a}$ & 37.5 \\
\hline Seasonal effects & $36.4^{\mathrm{A}}$ & $28.2^{\mathrm{B}}$ & $30.1^{\mathrm{B}}$ & \\
\hline \multicolumn{5}{|c|}{ LSD Seasons $(\mathrm{Y}): 5.5^{* *}, \mathrm{LSD}$ Treatments $(\mathrm{T}): 4.6^{* *}, \mathrm{LSD} \mathrm{Y} \times \mathrm{T}: 9.6 \mathrm{~ns}$} \\
\hline \multicolumn{5}{|c|}{ Mbawa Research Station } \\
\hline $\mathrm{CA}-\mathrm{PP}$ & $36.3^{\mathrm{a}}$ & $18.0^{\mathrm{c}}$ & $22.3^{\mathrm{dc}}$ & 25.5 \\
\hline CA sole maize & $39.3^{b}$ & $18.3^{\mathrm{c}}$ & $21.0^{\mathrm{c}}$ & 26.2 \\
\hline $\mathrm{CP}-\mathrm{PP}$ & $40.6^{\mathrm{a}}$ & $30.7^{\mathrm{a}}$ & $25.3^{\mathrm{a}}$ & 32.0 \\
\hline $\mathrm{CP}$ sole maize & $41.3^{\mathrm{a}}$ & $25.3^{b}$ & $17.9^{\mathrm{b}}$ & 26.7 \\
\hline Seasonal effects & $39.4^{\mathrm{A}}$ & $21.8^{\mathrm{C}}$ & $21.6^{\mathrm{B}}$ & \\
\hline \multicolumn{5}{|c|}{ LSD Seasons (Y): $2.68^{* * *}$, LSD Treatments $(\mathrm{T}): 3.09^{* * *} \mathrm{LSD} \mathrm{Y} \times \mathrm{T}: 5.36^{*}$} \\
\hline \multicolumn{5}{|c|}{ Chitala Research Station } \\
\hline $\mathrm{CA}-\mathrm{PP}$ & $41.7^{\mathrm{a}}$ & $67.0^{\mathrm{a}}$ & $34.7^{b}$ & 47.8 \\
\hline CA sole maize & $33.0^{\mathrm{b}}$ & $66.7^{\mathrm{a}}$ & $34.7^{b}$ & 44.8 \\
\hline $\mathrm{CP}-\mathrm{PP}$ & $40.0^{\mathrm{a}}$ & $64.3^{\mathrm{a}}$ & $34.3^{b}$ & 46.2 \\
\hline $\mathrm{CP}$ sole maize & $46.7^{\mathrm{a}}$ & $34.3^{b}$ & $41.3^{\mathrm{a}}$ & 50.3 \\
\hline Seasonal effects & $40.3^{B}$ & $65.2^{\mathrm{A}}$ & $36.2^{C}$ & \\
\hline
\end{tabular}

LSD Seasons (Y): $8.5^{* * *}$, LSD Treatments (T): $9.81 *$ LSD Y $\times$ T: $17.0 \mathrm{~ns}$

Values with the same letter under the same parameter are not significantly different at ${ }^{*}=p<0.05 ;{ }^{* *}=p<0.01$ ${ }^{* * *}=p<0.001 ; \mathrm{ns}=$ not significant at $p<0.05 ; \mathrm{LSD}$, least significant difference; CA-PP, push-pull system under conservation agriculture (CA) - maize/Desmodium intercropping; $\mathrm{CA}$ sole maize, sole maize cropping under $\mathrm{CA}$ $\mathrm{CP}-\mathrm{PP}$, push-pull system under $\mathrm{CP}$-maize/Desmodium intercropping; and $\mathrm{CP}$ sole maize, sole maize cropping under CP. Values with letters in the uppercase compare the means across the columns.

In Mbawa, the number of maize cobs harvested was significantly affected by the seasons and the treatments. The 2017-2018 season recorded a significantly higher maize cobs than the other two seasons (Table 4). In 2016-2017, CP, CP-PP, and CA showed higher numbers of cobs by 5.0,4.3, and 3 than CA-PP. In 2017-2018, CP-PP recorded a higher number of cobs by 5.4, 12.4, and 12.7 than CP, CA, and CA-PP. In 2018-2019, CP-PP recorded a higher number of cobs by 3.0, 4.3, and 7.4 than CA-PP, CA, and CP, respectively. There were significant differences between CA and CP but no differences between CA-PP and CA (Table 4). 
Table 4. Effects of growing seasons and treatments on the mean number of stemborer exit holes at Chitedze Research Station between the 2016-2017 and 2017-2018 seasons.

\begin{tabular}{|c|c|c|c|c|c|c|}
\hline & \multicolumn{2}{|c|}{ Growing Seasons } & \multicolumn{4}{|c|}{ Growing Seasons } \\
\hline & 2016-2017 & 2017-2018 & $\begin{array}{l}\text { Treatments } \\
\text { Effect }\end{array}$ & 2016-2017 & 2017-2018 & $\begin{array}{c}\text { Treatments } \\
\text { Effect }\end{array}$ \\
\hline Treatments & \multicolumn{2}{|c|}{$\begin{array}{l}\text { Number of Stemborer } \\
\text { Exit Holes }\end{array}$} & $\begin{array}{c}\text { Season } \\
\text { Mean }\end{array}$ & \multicolumn{2}{|c|}{ Stemborer Severity } & $\begin{array}{c}\text { Season } \\
\text { Mean }\end{array}$ \\
\hline $\mathrm{CA}-\mathrm{PP}$ & $3.10^{c}$ & $0.73^{b}$ & 1.92 & $2.0^{\mathrm{a}}$ & $1.3^{\mathrm{b}}$ & 1.7 \\
\hline $\begin{array}{l}\text { CA sole } \\
\text { maize }\end{array}$ & $3.13^{c}$ & $2.25^{\mathrm{a}}$ & 2.69 & $2.3^{\mathrm{ab}}$ & $1.7^{\mathrm{b}}$ & 2.0 \\
\hline $\mathrm{CP}-\mathrm{PP}$ & $3.79^{b}$ & $1.01^{\mathrm{b}}$ & 2.40 & $3.3^{c}$ & $3.0^{\mathrm{a}}$ & 3.2 \\
\hline $\begin{array}{l}\text { CP sole } \\
\text { maize }\end{array}$ & $4.23^{\mathrm{a}}$ & $2.20^{\mathrm{a}}$ & 3.22 & $3.6^{c}$ & $2.7^{\mathrm{a}}$ & 3.1 \\
\hline $\begin{array}{l}\text { Seasonal } \\
\text { effects }\end{array}$ & $3.56^{\mathrm{A}}$ & $1.56^{\mathrm{B}}$ & & $2.8^{\mathrm{A}}$ & $2.2^{B}$ & \\
\hline \multicolumn{7}{|c|}{$\begin{array}{l}\text { LSD Seasons (Y): } 0.307^{* * *} \text {, LSD Treatments }(\mathrm{T}): 0.409^{* * *}, \mathrm{LSD} \mathrm{Y} \times \mathrm{T}: 0.614 \mathrm{~ns} \\
\text { LSD Seasons (Y): } 0.819 \mathrm{~ns}, \text { LSD Treatments }(\mathrm{T}): 1.158^{* *}, \mathrm{LSD}, \mathrm{Y} \times \mathrm{T}: 1.639 \mathrm{~ns}\end{array}$} \\
\hline $\begin{array}{l}\text { alues with the } \\
*=p<0.001 ; n \\
\text { onservation ag } \\
\text { A; CP-PP, pu } \\
\text { laize, sole maiz }\end{array}$ & $\begin{array}{l}\text { ame letter unc } \\
=\text { not signific } \\
\text { iculture (CA) } \\
\text { h-pull system } \\
\text { cropping un }\end{array}$ & $\begin{array}{l}r \text { the same par } \\
t \text { at } p<0.05 ; \mathrm{L} \\
\text { maize/Desmo } \\
\text { ader conventi } \\
r \text { CP. Values w }\end{array}$ & $\begin{array}{l}\text { meter are not si } \\
\mathrm{D} \text {, least significa } \\
\text { ium intercroppi } \\
\text { al practice (CP) } \\
\text { th letters in upp }\end{array}$ & $\begin{array}{l}\text { gnificantly diff } \\
\text { nt difference; } \\
\text { g; CA sole ma } \\
\text { - maize/Desm }\end{array}$ & $\begin{array}{l}\text { ent at }{ }^{*}=p<0 \\
\text { - PP, push-p } \\
\text { ze, sole maize } \\
\text { ium intercropp }\end{array}$ & $\begin{array}{l}05 ;{ }^{* *}=p<0.01 \\
11 \text { system under } \\
\text { ropping under } \\
\text { ng; and CP sole }\end{array}$ \\
\hline
\end{tabular}

In Chitala, the season and the treatment significantly affected the number of cobs harvested. The 2017-2018 season had an increased number of maize cobs harvested. In 2016-2017, CP showed a significantly higher number of cobs (by 13.7) than CA, while in 2017-2018, CA, CP-PP, and CA-PP recorded a higher number of cobs, respectively, by 0.3 , 2.7, and 32.7 than CP. However, in 2018-2019, the number of cobs harvested under CP was higher by 7.0, 6.6, and 6.6 than CP-PP, CA, and CA-PP (Table 4).

\subsection{Effect on the Damage Level: Number of Stemborer Exit Holes}

The season and the treatment significantly affected the number of exit holes. During the 2016-2017 growing season, CP had more exit holes than CP-PP, CA, and CA-PP (respectively by $0.44,1.10$, and 1.13). There were significant differences between CP-PP on the one hand and CA and CA-PP on the other, but no significant differences were recorded between CA and CA-PP. Stemborer severity in CP was significantly higher by 1.3 and 1.6 than $\mathrm{CA}$ and $\mathrm{CA}-\mathrm{PP}$, respectively. There were also significant differences between $\mathrm{CP}, \mathrm{CA}$ and $\mathrm{CP}-\mathrm{PP}$. However, there were no significant differences between $\mathrm{CP}$ and $\mathrm{CP}-\mathrm{PP}$ and between CA and CA-PP (Table 4).

In the 2017-2018 season, CA-PP and CP-PP recorded significantly fewer numbers of stemborer exit holes than (CA-PP: 1.52 and 1.47 for CA and CP, respectively, and CP-PP: 1.24 and 1.19 for $\mathrm{CA}$ and $\mathrm{CP}$, respectively). Stemborer severity showed a similar trend to that of the previous year (Table 4).

\subsection{Striga Severity and Number of Plants Affected by Striga}

Striga severity was significantly affected by the seasons and treatments. The 2018-2019 season recorded significantly higher Striga severity than 2017-2018 (Table 5). In 2017-2018 the Striga severity was significantly higher by $0.6,0.7$, and 1 than CP-PP-CA and CA-PP. The number of plants affected by Striga reflected a similar trend as the severity score. 


\subsection{Striga Mapping}

The output map showed regions with high to low suitability for Striga occurrence in the whole country (Figure 4). The model predicted a very high Striga asiatica suitability in areas around the Mbawa and Chitedze Research Stations, whereas it was moderate to low in the Chitala Research Station area.

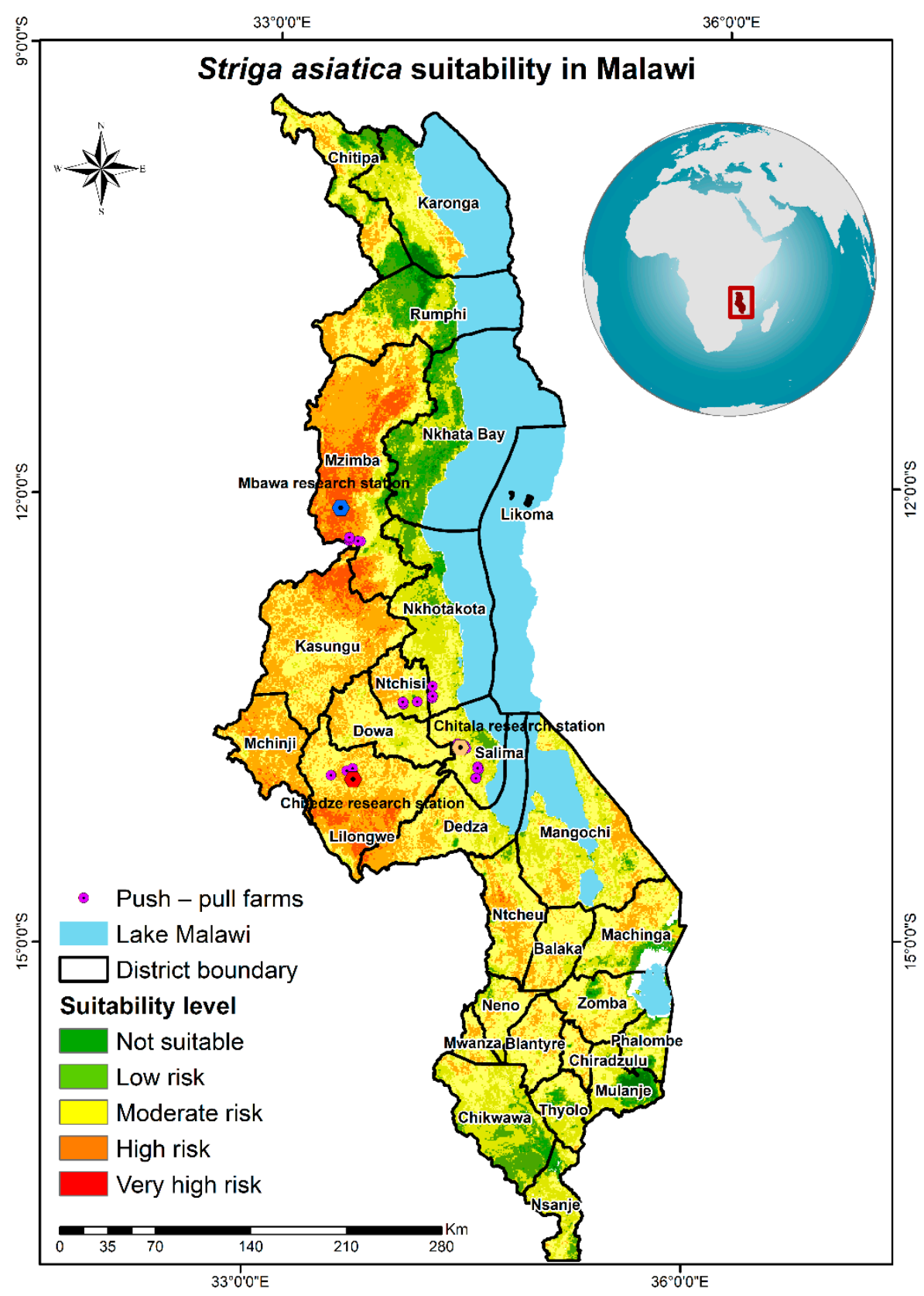

Figure 4. Predictive occurrence of Striga infestation in Malawi.

\subsection{Desmodium Climate Suitability Model}

The AUC values were all higher than 0.5 , indicating an optimal occurrence area in all the species (Figure 5). This shows that the model successfully predicted the suitable habitat area for the two Desmodium species. 

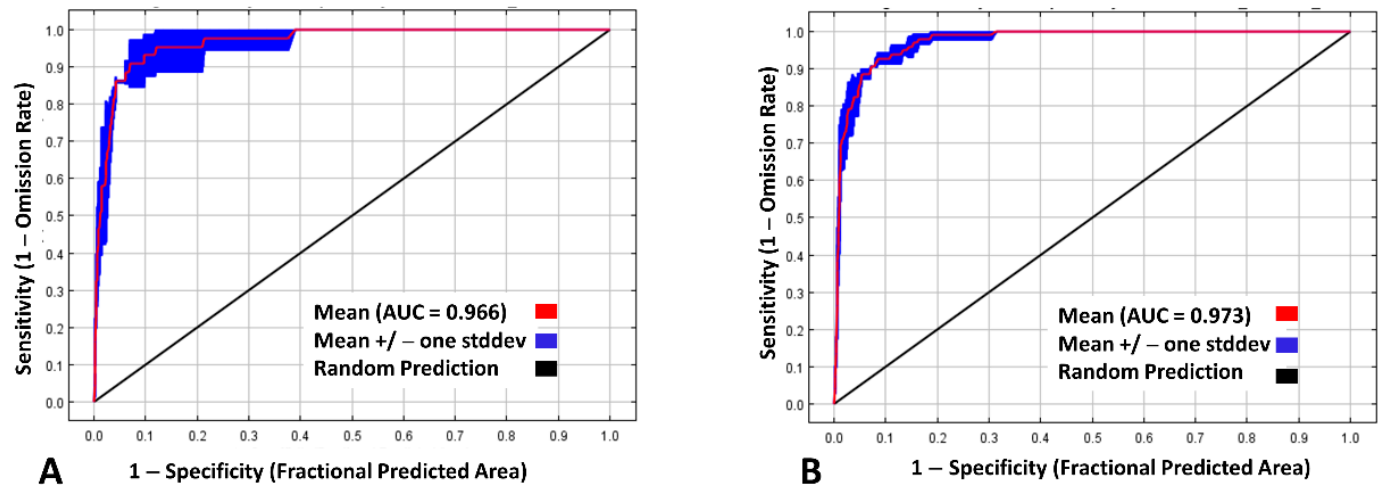

Figure 5. Receiver operating characteristic with the area under curve (AUC) graphs of the ensemble model outputs of predicting (A) Silverleaf and (B) Greenleaf Desmodium.

The jack-knife test demonstrated that precipitation of the warmest quarter (Bio_18) is the most important variable in determining the suitability of the two Desmodium species (Figure 6).
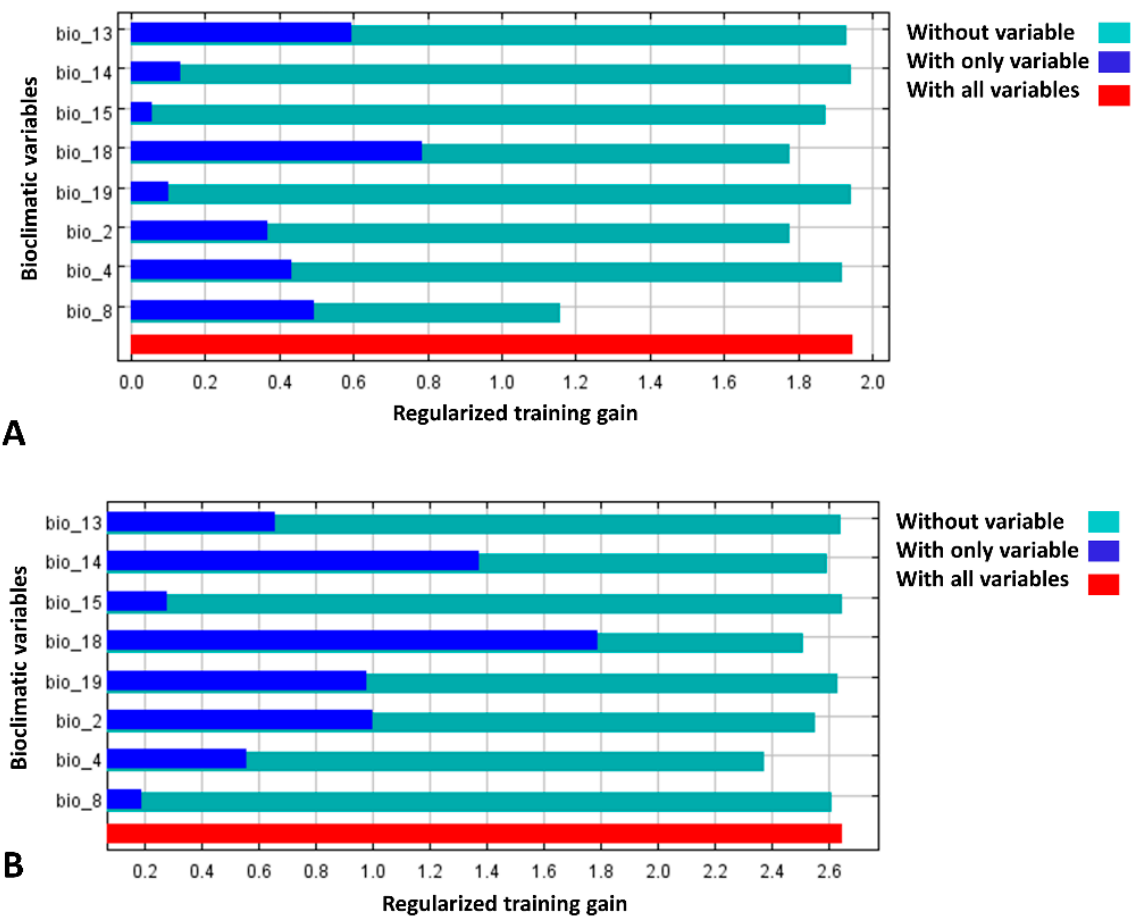

Figure 6. The relative importance of bioclimatic variables for predicting the climate suitability of (A) Silverleaf and (B) Greenleaf Desmodium based on the jack-knife test.

The response of Desmodium performance to the four most important bioclimatic variables is illustrated. The response curves of the four variables in the Silverleaf Desmodium model (Figure 7) indicated that Silverleaf Desmodium performs optimally at the precipitation of 400-600 $\mathrm{mm}$ in the warmest quarter (Figure 7A) and up to $1200 \mathrm{~mm}$ in the wettest month (Figure 7C). The forage legume thrives in a mean temperature of $20^{\circ} \mathrm{C}$ in the wettest quarter (Figure 7B) and a mean diurnal temperature range of $6-10^{\circ} \mathrm{C}$ (Figure 7D).

The response curves of the four variables in the Greenleaf Desmodium model (Figure 8) indicated that Greenleaf Desmodium performs optimally at the precipitation of 400-1400 mm in the warmest quarter (Figure 8A) and between $20-160 \mathrm{~mm}$ in the driest month (Figure 8C). It thrives well even with a high temperature seasonality (Figure 8B) and a mean diurnal temperature range of $6-8{ }^{\circ} \mathrm{C}$ (Figure 8D). 

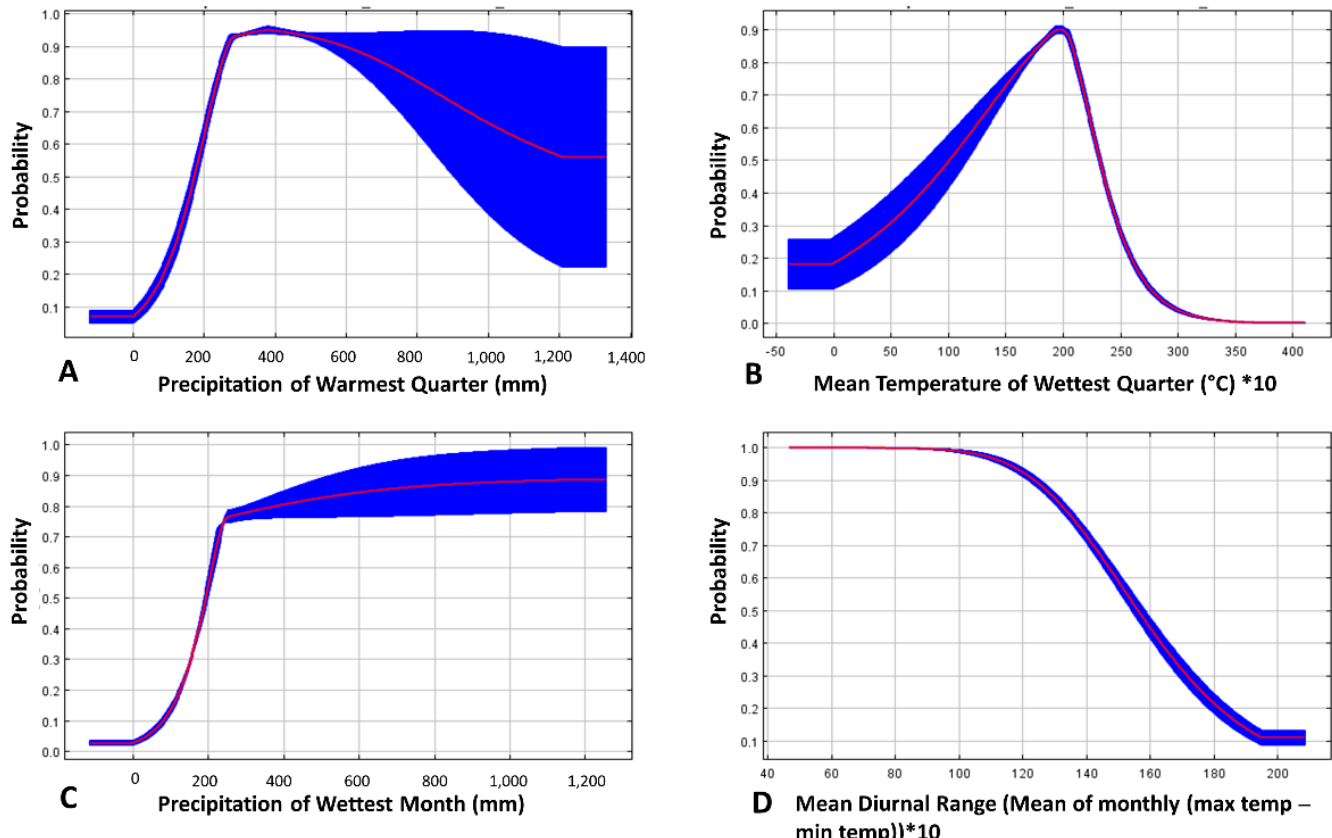

Mean $\square$

Mean $+/-$ standard deviation $\quad *$ - Multiplication

Figure 7. Response curves for the selected bioclimatic variables to predict suitable habitats for Silverleaf Desmodium in Malawi. The star $\left(^{*}\right)$ means multiplication.
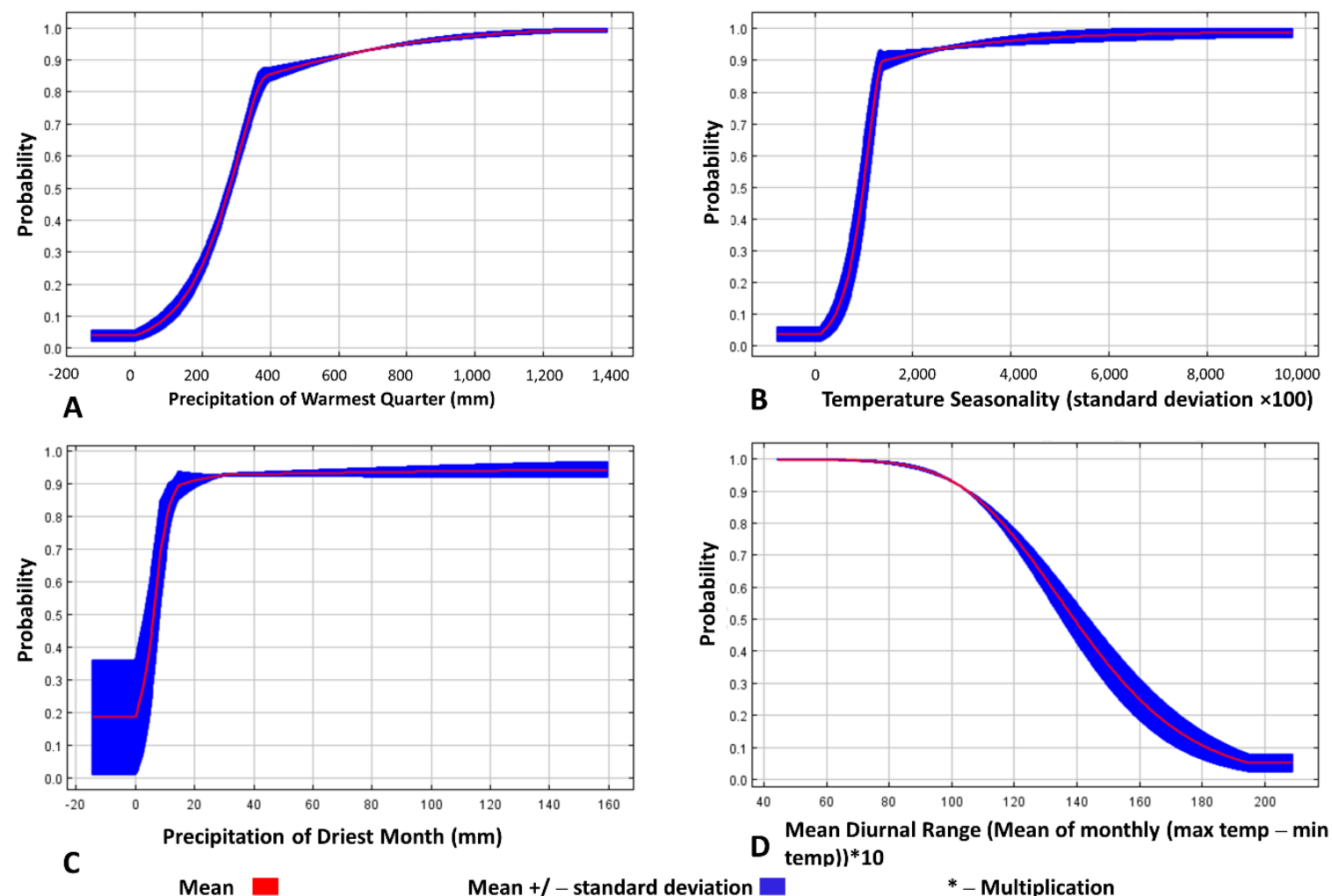

Figure 8. Response curves for the selected bioclimatic variables to predict suitable habitats for Greenleaf Desmodium in Malawi. The star $\left(^{*}\right)$ means multiplication. 
A comparison of the two models indicated that Silverleaf Desmodium generally has higher suitability than Greenleaf Desmodium across all the districts in Malawi (Figure 9). The suitability of Greenleaf Desmodium used in this study in the target districts was found to be very low (Figure 9).
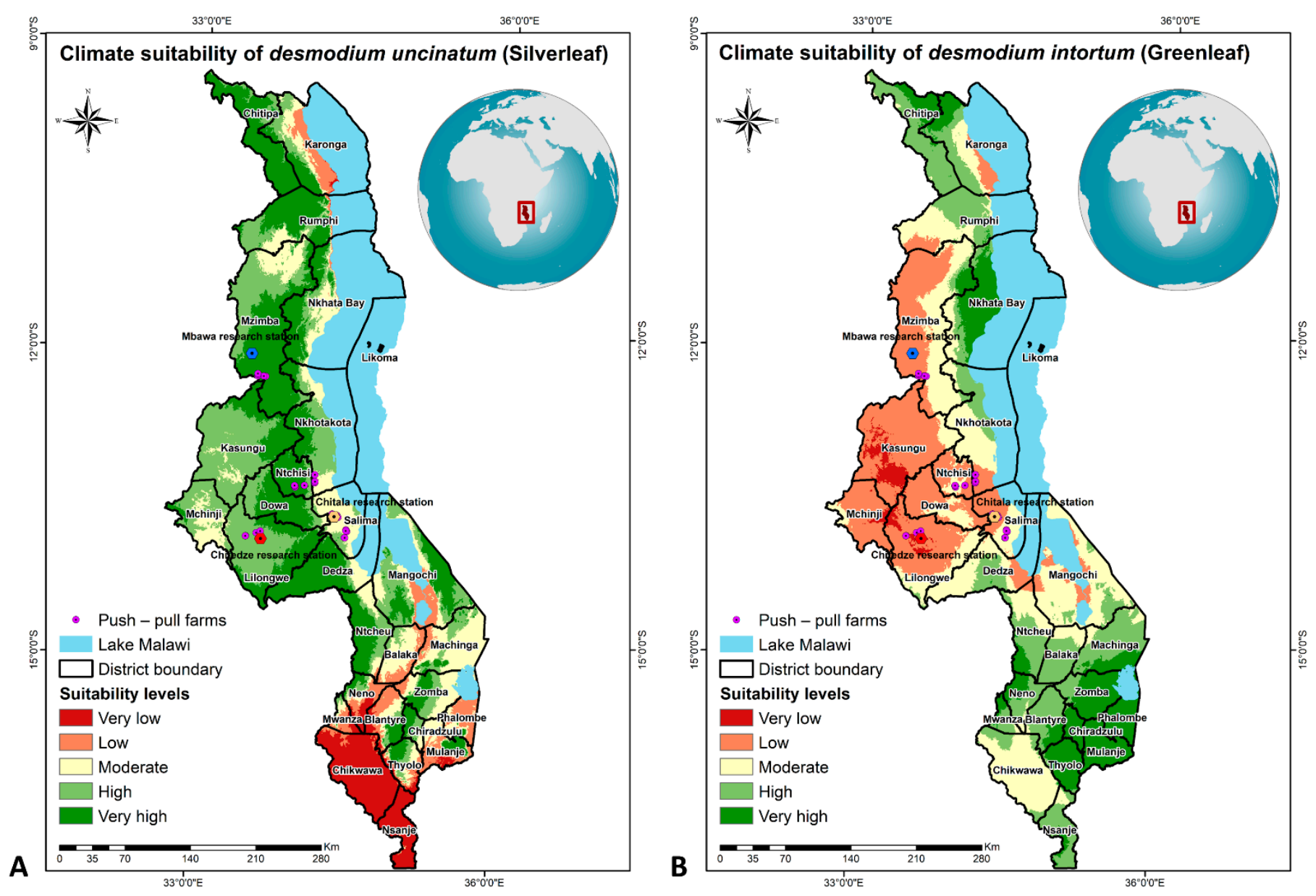

Figure 9. Predicted climate suitability of (A) Silverleaf and (B) Greenleaf Desmodium in Malawi.

\subsection{Focus Group Discussions}

After introducing PPT, farmers showed much enthusiasm in taking up the technology since they noticed that it could significantly reduce Striga weed and stemborer pests by up to $70 \%$. They also attested that they had seen a significant increase in maize yield (Table 7). However, the cost of labour in terms of ploughing, planting, weeding, harvesting, and threshing was higher in PPT-based treatments. 
Table 7. Profitability analysis of CA-PP technology in Malawi (per hectare of land) during the baseline survey.

\begin{tabular}{|c|c|c|c|c|c|}
\hline \multicolumn{6}{|c|}{ With Conservation Agriculture and Push-Pull Technology (CA-PP) } \\
\hline District & $\begin{array}{c}\text { Ploughing and } \\
\text { Planting (Person-Days) }\end{array}$ & $\begin{array}{c}\text { Weeding } \\
\text { (Person-Days) }\end{array}$ & $\begin{array}{c}\text { Harvesting } \\
\text { (Person-Days) }\end{array}$ & $\begin{array}{c}\text { Threshing } \\
\text { (Person-Days) }\end{array}$ & Yield (kg/ha) \\
\hline Lilongwe & 24 & 16 & 12 & 12 & 2400 \\
\hline Salima & 56 & 24 & 48 & 14 & 6400 \\
\hline Nkhotakota & 50 & 20 & 24 & 18 & 2880 \\
\hline Mzimba & 44 & 21 & 42 & 56 & 4000 \\
\hline Mean & 44 & 20 & 32 & 25 & 3920 \\
\hline \multicolumn{6}{|c|}{ Without Conservation Agriculture and Push-Pull Technology (CA-PP) } \\
\hline Lilongwe & 8 & 12 & 8 & 6 & 1200 \\
\hline Salima & 36 & 18 & 32 & 8 & 3600 \\
\hline Nkhotakota & 28 & 12 & 18 & 14 & 1920 \\
\hline Mzimba & 22 & 12 & 35 & 42 & 3200 \\
\hline Mean & 24 & 14 & 23 & 18 & 2480 \\
\hline
\end{tabular}

\section{Discussion}

Despite deficient soils and erratic rainfall patterns, the expected agronomic benefits in yield, pest management, and plant features were achieved under CA and CP. The PPT performed well in Chitedze in the 2016-2017 season, in Mbawa in the 2017-2018 and 20182019 seasons, and in Chitala in 2016-2017 and 2017-2018 seasons. The lack of consistency in performance can be linked to the variabilities between the sites [1,2]. Crop performance in terms of yield was related to soil physicochemical properties (Table 8). Soil analysis results showed an excess of potassium in all samples. Mbawa soils are acidic and deficient in nutrients, including nitrogen, essential for maize growth. Chitedze soils are also acidic and deficient in nitrogen and phosphorus, and their $\mathrm{pH}$ is moderately acidic. Chitala soils are less acidic than others, often with an excess of phosphorus. Areas with high deficiency seemed more favourable for sole maize due to interspecific competition between maize, Desmodium, and Brachiaria. PPT seemed to be more compatible with CP in low-fertility soils.

Table 8. Correlation matrix between maize yield and physicochemical properties of the soils.

\begin{tabular}{|c|c|c|c|c|c|c|c|c|c|c|c|c|}
\hline Years & $\begin{array}{c}\text { Correlation } \\
\text { Coefficient } / p \\
\text { Value }\end{array}$ & $\mathrm{pH}$ & OC & OM & $\mathbf{N}$ & $\mathbf{P}$ & $\mathbf{K}$ & $\mathrm{Ca}$ & Mg & Clay & Silt & Rainfall \\
\hline \multirow{2}{*}{2017} & $\mathrm{R}$ & 0.303 & 0.175 & 0.160 & 0.217 & 0.632 & 0.524 & 0.426 & 0.555 & -0.050 & 0.145 & 0.038 \\
\hline & $p$ value & 0.338 & 0.587 & 0.619 & 0.498 & 0.028 & 0.080 & 0.167 & 0.061 & 0.877 & 0.654 & 0.462 \\
\hline \multirow{2}{*}{2018} & $\mathrm{R}$ & 0.637 & 0.537 & 0.530 & 0.542 & 0.337 & 0.763 & 0.065 & 0.737 & 0.239 & 0.433 & 0.546 \\
\hline & $p$ value & 0.026 & 0.072 & 0.076 & 0.069 & 0.283 & 0.004 & 0.842 & 0.006 & 0.454 & 0.160 & 0.290 \\
\hline \multirow{2}{*}{2019} & $\mathrm{R}$ & -0.026 & -0.178 & -0.181 & -0.153 & 0.041 & -0.128 & 0.205 & -0.068 & -0.037 & 0.143 & 0.064 \\
\hline & $p$ value & 0.937 & 0.580 & 0.574 & 0.635 & 0.899 & 0.692 & 0.523 & 0.834 & 0.909 & 0.657 & 0.750 \\
\hline \multirow{2}{*}{ Combined } & $\mathrm{R}$ & 0.344 & 0.243 & 0.234 & 0.263 & 0.368 & 0.463 & 0.208 & 0.472 & 0.064 & 0.228 & 0.076 \\
\hline & $p$ value & 0.040 & 0.154 & 0.169 & 0.121 & 0.027 & 0.004 & 0.223 & 0.004 & 0.712 & 0.181 & 0.255 \\
\hline
\end{tabular}

Desmodium is a perennial plant that expands its root system in subsequent seasons [50]. $\mathrm{CP}$ supports ploughing, and the disturbance caused to the roots prevents competition for nutrients between maize and the companion plants (Desmodium and Brachiaria). PPT was only compatible with CA in Chitala, where soil nutrients were balanced. Results on grain yield and the number of cobs in that region testified to the agronomic performance of PPT under CA. In addition to these variabilities, the rainfall pattern may interfere with a crop's agronomic performance [51]. Seasons 2016-2017 and 2018-2019 had better rains than 2017-2018, except in Chitala, where the 2018-2019 season was not very impressive.

Observation of the numbers of exit holes found at Chitedze indicated that in 20162017, PPT and sole maize under CA had the lowest numbers. In 2017-2018, PPT under 
CA and CP had the lowest exit holes. These results confirm previous findings of the superiority of PPT over convention practice in reducing lepidopteran pests, as described by Midega et al. [24], Hailu et al. [27], and Ndayisaba et al. [52]. These findings imply that maize under PPT produces better yields and has less ear rot, and hence fewer chances of Aflatoxin contamination, as reflected in the severity scores [53]. Both PPT and CA promote the presence of natural enemies, which support a more efficient control of the pest in subsequent seasons. In that regard, a spillover effect in adjacent control plots can be envisaged; hence, agronomic attributes in terms of plant vigour and height are the discriminating factors between treatments.

Both PPT and CA are soil-fertility-increasing technologies. CA is designed to increase biological diversity, reduce runoff and erosion, improve soil organic carbon, and improve crop yield [54-56]. Likewise, PPT improves soil moisture and nitrogen fixation, and Desmodium suppresses Striga through root exudates, mainly Isoschaftoside, a C-glycosylflavonoid, leading to suicidal germination of Striga seeds [57]. This has been confirmed in many earlier studies [52,58,59]. Additional attributes of PPT can be observed in Chitedze, whereby PPT maize plants in CP (2016-2017) and PPT maize plants under CA 2017-2018 were taller than the plants in the other treatments. It can be concluded that the application of PPT or CA contributes to a drastic reduction in Striga through soil fertility improvement.

Desmodium Greenleaf has very low suitability in the target sites. Desmodium Greenleaf originates from South America and requires neutral soils $(\mathrm{pH}<7)$ [60]. Its optimal temperature ranges between 25 and $30^{\circ} \mathrm{C}$, and it performs better between 500 and $2500 \mathrm{~m}$ in the tropics where annual rainfall is above $900 \mathrm{~mm}$ and up to $3000 \mathrm{~mm}$ [60]. In that regard, Desmodium Silverleaf showed a much higher coverage and suitability in the country.

PPT is a sustainable and low-input production system that relies on household labour for ploughing, planting, weeding, harvesting, and threshing. PPT does not require external inputs such as chemical pesticides to reduce incidences of stemborer and Striga in maize. Farmers involved in the FGDs reported increased productivity between $45-50 \%$ and improved arthropod abundance, soil biota and soil organic matter, and overall environmental health. Recently, PPT was found to control FAW, a serious invasive pest of cereal crops in Africa [24,27]. Therefore, dissemination and outreach campaigns need to emphasize the multiple benefits of the technology, including the use of Brachiaria and Desmodium and fodder crops [61,62].

The FGDs showed that farmers considered PPT as a yield-increasing technology. However, the initial establishment and planting of PPT requires ploughing and harrowing the land to a fine tilth for the sowing of Desmodium seeds and the general layout of the plot. Several studies have demonstrated that the cost of the initial establishment might be high, but it is reduced over time.

\section{Conclusions}

This study is the first to investigate PPT's performance in various agroecological zones in Malawi under two farming practices. The study confirmed the classical benefits of technology in terms of stemborer and Striga control. However, PPT was more compatible with $\mathrm{CP}$ in low-soil-fertility areas, probably due to below-ground competition under $\mathrm{CA}$. The combination of PPT and CA can only occur in areas of moderate soil fertility. Root pruning is therefore compulsory to avoid plant stunting in subsequent seasons. The combination of PPT and CA was very effective in controlling Striga. Desmodium Silverleaf is more suitable in Malawi than Greenleaf is. While further research is needed to identify indigenous Desmodium, the current study supports the release of the technology in Malawi. Desmodium and Brachiaria as animal fodder can offer a comparative advantage for adopting the technology. 
Author Contributions: Conceptualization, S.N., G.H., I.L., M.K. and Z.K.; methodology, S.N., G.H., I.L., M.K. and Z.K.; validation, S.N., D.K., I.L., G.H., E.K., J.P. and M.K.; formal analysis, M.K.A., B.T.M., D.K., E.K. and N.O.; investigation, S.N., M.K.A., B.T.M., D.K., I.L., G.H., E.K., N.O., M.K. and Z.K.; resources, S.N., J.P., M.K. and Z.K.; data curation, M.K.A., B.T.M., D.K., E.K. and N.O. writing-original draft preparation, S.N., M.K.A., G.H., E.K., N.O. and J.P., writing-review and editing, S.N., M.K.A., B.T.M., D.K., I.L., G.H., E.K., Z.J., N.O., J.P., M.K. and Z.K.; visualization, M.K.A., B.T.M., D.K., E.K. and N.O.; supervision, S.N., J.P., M.K. and Z.K.; project administration, S.N., I.L., G.H., Z.J., J.P., M.K. and Z.K.; funding acquisition, S.N., J.P. and Z.K. All authors have read and agreed to the published version of the manuscript.

Funding: Biovision Foundation Switzerland funded the present study in the context of Push-Pull for Sub-Saharan Africa (DPP-010 ICIPE). We also gratefully acknowledge the financial support for the core research agenda of ICIPE by the Swedish International Development Cooperation Agency (SIDA), the Swiss Agency for Development and Cooperation (SDC), and the Kenyan Government.

Institutional Review Board Statement: Not applicable.

Informed Consent Statement: Not applicable.

Data Availability Statement: Not applicable.

Acknowledgments: The authors gratefully acknowledge the financial support for this research by the following organizations and agencies: Biovision Foundation Switzerland, the project donor (DPP-010 ICIPE); USAID/OFDA (which contributed to the national capacity that enabled the data to be generated); the Norwegian Agency for Development Cooperation, the section for research, innovation, and higher education grant number RAF-3058 KEN-18/0005 (CAP-Africa); the Swiss Agency for Development and Cooperation (SDC); the Federal Democratic Republic of Ethiopia; and the Government of the Republic of Kenya. The views expressed herein do not necessarily reflect the official opinions of the donors. The authors express their gratitude to Total Land Care-TLC-Malawi, the farmers, the extension agents, and all the technical staff involved in the data collection in the different EPAs. We thank the Department of Agricultural Research Services DARS, which collected the data used in this paper.

Conflicts of Interest: The authors declare no conflict of interest. The funders had no role in the design of the study, in the collection, analyses, or interpretation of data, in the writing of the manuscript, or in the decision to publish the results.

\section{References}

1. Thierfelder, C.; Matemba-Mutasa, R.; Bunderson, W.T.; Mutenje, M.; Nyagumbo, I.; Mupangwa, W. Evaluating manual conservation agriculture systems in southern Africa. Agric. Ecosyst. Environ. 2016, 222, 112-124. [CrossRef]

2. Ngwira, A.R.; Thierfelder, C.; Lambert, D.M. Conservation agriculture systems for Malawian smallholder farmers: Long-term effects on crop productivity, profitability and soil quality. Renew. Agric. Food Syst. 2013, 28, 350-363. [CrossRef]

3. Khan, Z.R.; Midega, C.A.O.; Bruce, T.J.A.; Hooper, A.M.; Pickett, J.A. Exploiting phytochemicals for developing a "push-pull" crop protection strategy for cereal farmers in Africa. J. Exp. Bot. 2010, 61, 4185-4196. [CrossRef] [PubMed]

4. Tefera, T.; Mugo, S.; Mwimali, M.; Anani, B.; Tende, R.; Beyene, Y.; Gichuki, S.; Oikeh, S.O.; Nang'ayo, F.; Okeno, J.; et al. Resistance of Bt-maize (MON810) against the stem borers Busseola fusca (Fuller) and Chilo partellus (Swinhoe) and its yield performance in Kenya. Crop Prot. 2016, 89, 202-208. [CrossRef] [PubMed]

5. Mloza-Banda, H.; Kabambe, V. Integrated management for Striga control in Malawi. Afr. Crop Sci. J. 1996, 4, $263-273$.

6. Kabambe, V.H.; Resources, N.; Kanampiu, F. Evaluation of the use of herbicide (Imazapyr) and fertilizer application in integrated management of Striga asiatica in maize in Malawi. Afr. J. Agric. Res. 2007, 2, 687-691.

7. Bouwmeester, H.; Manyong, V.; Mutabazi, K.; Maeda, C.; Omanya, G.; Mignouna, H.; Bokanga, M. Spatial Analysis of Livelihoods of Smallholder Farmers in Striga-Infested Maize-Growing Areas of Eastern and Southern Africa; International Institute of Tropical Agriculture: Ibadan, Nigeria; African Agricultural Technology Foundation (AATF): Nairobi, Kenya, 2009.

8. Ngwira, A.R.; Aune, J.B.; Thierfelder, C. DSSAT modelling of conservation agriculture maize response to climate change in Malawi. Soil Tillage Res. 2014, 143, 85-94. [CrossRef]

9. Kumar, R.; Jindal, J. Economic evaluation of biorational and conventional insecticides for the control of maize stem borer Chilo partellus (Swinhoe) in Zea mays. J. Appl. Nat. Sci. 2015, 7, 644-648. [CrossRef]

10. Lichtfouse, E.; Navarrete, M.; Debaeke, P.; Souchère, V.; Alberola, C.; Ménassieu, J. Agronomy for sustainable agriculture. A review. Agron. Sustain. Dev. 2009, 29, 1-6. [CrossRef]

11. Agboka, K.; Mawufe, A.K.; Tamò, M.; Vidal, S. Effects of plant extracts and oil emulsions on the maize cob borer Mussidia nigrivenella (Lepidoptera: Pyralidae) in laboratory and field experiments. Int. J. Trop. Insect Sci. 2009, 29, 185-194. [CrossRef] 
12. Badji, A.; Otim, M.H.; Kyamanywa, S. Maize resistance to stem borers and storage pests: The need for new genetic and functional genomics approaches in future research. Afr. J. Rural Dev. 2017, 2, 467-479.

13. Conlong, D.E. Biological control of indigenous African stemborers: What do we know? Int. J. Trop. Insect Sci. 2001, 21, 267-274. [CrossRef]

14. Belay, D.; Foster, J.E. Efficacies of habitat management techniques in managing maize stem borers in Ethiopia. Crop Prot. 2010, 29, 422-428. [CrossRef]

15. Khan, Z.R.; Pickett, J.A.; Wadhams, L.; Muyekho, F. Habitat management strategies for the control of cereal stemborers and Striga in maize in Kenya. Int. J. Trop. Insect Sci. 2001, 21, 375-380. [CrossRef]

16. Dougill, A.J.; Whitfield, S.; Stringer, L.C.; Vincent, K.; Wood, B.T.; Chinseu, E.L.; Steward, P.; Mkwambisi, D.D. Mainstreaming conservation agriculture in Malawi: Knowledge gaps and institutional barriers. J. Environ. Manag. 2017, 195, 25-34. [CrossRef]

17. Fisher, M.; Holden, S.T.; Thierfelder, C.; Katengeza, S.P. Awareness and adoption of conservation agriculture in Malawi: What difference can farmer-to-farmer extension make? Int. J. Agric. Sustain. 2018, 16, 310-325. [CrossRef]

18. Nyagumbo, I.; Mkuhlani, S.; Pisa, C.; Kamalongo, D.; Dias, D.; Mekuria, M. Maize yield effects of conservation agriculture based maize-legume cropping systems in contrasting agro-ecologies of Malawi and Mozambique. Nutr. Cycl. Agroecosys. 2016, 105, 275-290. [CrossRef]

19. Nyagumbo, I.; Mkuhlani, S.; Mupangwa, W.; Rodriguez, D. Planting date and yield benefits from conservation agriculture practices across Southern Africa. Agric. Syst. 2017, 150, 21-33. [CrossRef]

20. World Bank. Malawi Economic Monitor June 2019: Charting a New Course; World Bank: Washington, DC, USA, 2019.

21. Day, R.; Abrahams, P.; Bateman, M.; Beale, T.; Clottey, V.; Cock, M.; Colmenarez, Y.; Corniani, N.; Early, R.; Godwin, J.; et al. Fall armyworm: Impacts and implications for Africa. Outlooks Pest Manag. 2017, 28, 196-201. [CrossRef]

22. Midega, C.A.O.; Salifu, D.; Bruce, T.J.; Pittchar, J.; Pickett, J.A.; Khan, Z.R. Cumulative effects and economic benefits of intercropping maize with food legumes on Striga hermonthica infestation. Field Crops Res. 2014, 155, 144-152. [CrossRef]

23. Khan, Z.R.; Midega, C.A.O.; Pittchar, J.O.; Pickett, J.A. Exploiting phytochemicals for developing sustainable crop protection strategies to withstand climate change: Example from Africa. In Advances in Plant Biopesticides; Springer: New Delhi, India, 2014; pp. 35-46. ISBN 9788132220060.

24. Midega, C.A.O.; Pittchar, J.O.; Pickett, J.A.; Hailu, G.W.; Khan, Z.R. A climate-adapted push-pull system effectively controls fall armyworm, Spodoptera frugiperda (J E Smith), in maize in East Africa. Crop Prot. 2018, 105, 10-15. [CrossRef]

25. Mudereri, B.T.; Abdel-Rahman, E.M.; Dube, T.; Niassy, S.; Khan, Z.; Tonnang, H.E.Z.; Landmann, T. A two-step approach for detecting Striga in a complex agroecological system using Sentinel-2 data. Sci. Total Environ. 2021, 762, 143151. [CrossRef]

26. Khan, Z.R.; Midega, C.A.O.; Pittchar, J.O.; Murage, A.W.; Birkett, M.A.; Bruce, T.J.A.; Pickett, J.A. Achieving food security for one million sub-Saharan African poor through push-pull innovation by 2020. Philos. Trans. R. Soc. B Biol. Sci. 2014, $369,20120284$. [CrossRef]

27. Hailu, G.; Niassy, S.; Zeyaur, K.R.; Ochatum, N.; Subramanian, S. Maize-legume intercropping and push-pull for management of fall armyworm, stemborers, and Striga in Uganda. Agron. J. 2018, 110, 2513-2522. [CrossRef]

28. Khan, Z.R.; Pickett, J.A.; Wadhams, L.J.; Hassanali, A.; Midega, C.A.O. Combined control of Striga hermonthica and stemborers by maize-Desmodium spp. intercrops. Crop Prot. 2006, 25, 989-995. [CrossRef]

29. Atera, E.A.; Ishii, T.; Onyango, J.C.; Itoh, K.; Azuma, T. Striga infestation in Kenya: Status, distribution and management options. Sustain. Agric. Res. 2013, 2, 99-108. [CrossRef]

30. Murage, A.W.; Midega, C.A.O.; Pittchar, J.O.; Pickett, J.A.; Khan, Z.R. Determinants of adoption of climate-smart push-pull technology for enhanced food security through integrated pest management in eastern Africa. Food Secur. 2015, 7, 709-724. [CrossRef]

31. Mudereri, B.T.; Abdel-Rahman, E.M.; Dube, T.; Landmann, T.; Khan, Z.R.; Kimathi, E.; Owino, R.; Niassy, S. Multi-source spatial data-based invasion risk modeling of Striga (Striga asiatica) in Zimbabwe. GIScience Remote Sens. 2020, 57, 553-571. [CrossRef]

32. Anderson, J.M.; Ingram, J.S.I. Tropical Soil Biology and Fertility: A Handbook of Methods, 2nd ed.; CAB International: Wallingford, UK, 1993.

33. Mehlich, A. Mehlich 3 soil test extractant: A modification of Mehlich 2 extractant, communications in soil science and plant analysis. Commun. Soil Sci. Plant Anal. 1984, 15, 1409-1416. [CrossRef]

34. FAO. Conservation Agriculture. Available online: http:/ /www.fao.org/ag/ca/1a.html (accessed on 16 February 2017).

35. Nyirenda, N.; Saka, A. Enhancing soil productivity for sustained food production for small-scale farmers in Malawi: A Sasakawa global 2000 and agricultural extension partnership initiative. In Proceedings of the Seventh Eastern and Southern Africa Regional Maize Conference, Nairobi, Kenya, 11-15 February 2001; International Maize and Wheat Centre (CIMMYT) and Kenya Agricultural Research Institute (KARI): Nairobi, Kenya, 2001.

36. Khan, Z.; Pickett, A.; Pittchar, J.; Genga, G.; Ndiege, A.; Nyagol, D. A Primer on Planting and Managing 'Push-Pull' Fields for Stemborer and Striga Weed Control in Maize-A Step-by-Step Guide for Farmers and Extension Staff, 3rd ed.; International Centre of Insect Physiology and Ecology: Nairobi, Kenya, 2019; ISBN 9789966063250.

37. Lark, R.M.; Ligowe, I.S.; Thierfelder, C.; Magwero, N.; Namaona, W.; Njira, K. Longitudinal analysis of a long-term conservation agriculture experiment in Malawi and lessons for future experimental design. Exp. Agric. 2020, 54, 506-527. [CrossRef] 
38. Berner, D.K.; Winslow, M.D.; Awad, A.E.; Cardwell, K.F.; Raj, D.R.M.; Kim, S.K. Striga Research Methods. A Manual, 2nd ed.; Pan-African Striga Control Network; International Institute of Tropical Agriculture (IITA): Ibadan, Nigeria, 1997; pp. 1-80. Available online: https://biblio1.iita.org/bitstream/handle/20.500.12478/3941/U97ManBernerStrigaNothomNodev.pdf?sequence=1 (accessed on 1 September 2021).

39. Ampofo, J.K.O. Maize Stalk Borer (Lepidoptera: Pyralidae) Damage and Plant Resistance. Environ. Entomol. 1986, 15, 1124-1129. [CrossRef]

40. ESRI. What is ArcGIS 9.2. 2006. Available online: https: / $/$ www.google.com.hk/url? sa $=t \& r c t=j \& q=\& e s r c=s \& s o u r c e=w e b \& c d=$ \&cad=rja\&uact=8\&ved=2ahUKEwjKnpb4o_71AhUdklYBHX6-AFsQFnoECAMQAQ\&url=https\%3A\%2F\%2Fwww.canyonco org\%2Fwp-content\%2Fuploads\%2F2016\%2F04\%2Fwhat-is-arcgis92.pdf\&usg=AOvVaw3OmdujQfs1X-mFg3I39UED (accessed on 1 September 2021).

41. Basharat, M.; Shah, H.R.; Hameed, N. Landslide susceptibility mapping using GIS and weighted overlay method: A case study from NW Himalayas, Pakistan. Arab. J. Geosci. 2016, 9, 292. [CrossRef]

42. Phillips, S.J.; Dudík, M.; Schapire, R.E. Maxent Software for Modeling Species Niches and Distributions; Version 3.4.1; American Museum of Natural History: New York, NY, USA, 2022; Available online: http://biodiversityinformatics.amnh.org/open_ source/maxent/ (accessed on 11 February 2021).

43. Mudereri, B.T.; Kimathi, E.; Chitata, T.; Moshobane, M.C.; Abdel-Rahman, E.M. Landscape-scale biogeographic distribution analysis of the whitefly, Bemisia tabaci (Gennadius, 1889) in Kenya. Int. J. Trop. Insect Sci. 2021, 41, 1585-1599. [CrossRef]

44. Naimi, B.; Hamm, N.A.S.; Groen, T.A.; Skidmore, A.K.; Toxopeus, A.G. Where is positional uncertainty a problem for species distribution modelling? Ecography 2014, 37, 191-203. [CrossRef]

45. R Core Team. R: A Language and Environment for Statistical Computing; R Foundation for Statistical Computing: Vienna, Austria, 2022; Available online: https:/ / www.R-project.org/ (accessed on 11 February 2021).

46. Moshobane, M.C.; Mudereri, B.T.; Mukundamago, M.; Chitata, T. Predicting future distribution patterns of Jatropha gossypiifolia L. in South Africa in response to climate change. S. Afr. J. Bot. 2022, 146, 417-425. [CrossRef]

47. Chemura, A.; Mudereri, B.T.; Yalew, A.W.; Gornott, C. Climate change and specialty coffee potential in Ethiopia. Sci. Rep. 2021, 11, 8097. [CrossRef] [PubMed]

48. Allouche, O.; Tsoar, A.; Kadmon, R. Assessing the accuracy of species distribution models: Prevalence, kappa and the true skill statistic (TSS). J. Appl. Ecol. 2006, 43, 1223-1232. [CrossRef]

49. Lobulu, J.; Shimelis, H.; Laing, M.; Mushongi, A.A. Maize production constraints, traits preference and current Striga control options in western Tanzania: Farmers' consultation and implications for breeding. Acta Agric. Scand. Sect. B Soil Plant Sci. 2019, 69, 734-746. [CrossRef]

50. Heuzé, V.; Tran, G.; Eugène, M.; Bastianelli, D. Silverleaf Desmodium (Desmodium uncinatum). Feedipedia, a Programme by INRA, CIRAD, AFZ and FAO. Available online: http:/ / www.feedipedia.org/node/299 (accessed on 3 February 2017).

51. Mupangwa, W.; Mutenje, M.; Thierfelder, C.; Nyagumbo, I. Are conservation agriculture (CA) systems productive and profitable options for smallholder farmers in different agro-ecoregions of Zimbabwe? Renew. Agric. Food Syst. 2016, 32, 87-103. [CrossRef]

52. Ndayisaba, P.C.; Kuyah, S.; Midega, C.A.O.; Mwangi, P.N.; Khan, Z.R. Intercropping Desmodium and maize improves nitrogen and phosphorus availability and performance of maize in Kenya. Field Crops Res. 2021, 263, 108067. [CrossRef]

53. Njeru, N.K.; Midega, C.A.O.; Muthomi, J.W.; Wagacha, J.M.; Khan, Z.R. Influence of socio-economic and agronomic factors on aflatoxin and fumonisin contamination of maize in western Kenya. Food Sci. Nutr. 2019, 7, 2291-2301. [CrossRef]

54. Babiker, A.G.T.; Hamdoun, A.M.; Rudwan, A.; Mansi, N.G.; Faki, H.H. Influence of soil moisture on activity and persistence of the strigol analogue GR 24. Weed Res. 1987, 27, 173-178. [CrossRef]

55. Mashavakure, N.; Mashingaidze, A.B.; Musundire, R.; Gandiwa, E.; Thierfelder, C.; Muposhi, V.K.; Svotwa, E. Influence of tillage, fertiliser regime and weeding frequency on germinable weed seed bank in a subhumid environment in Zimbabwe. S. Afr. J. Plant Soil 2019, 36, 319-327. [CrossRef]

56. Muthoni, F.; Thierfelder, C.; Mudereri, B.T.; Manda, J.; Bekunda, M.; Hoeschle-Zeledon, I. Machine learning model accurately predict maize grain yields in conservation agriculture systems in Southern Africa. In Proceedings of the 20219 th International Conference on Agro-Geoinformatics (Agro-Geoinformatics), Shenzhen, China, 26-29 July 2021; pp. 1-5. [CrossRef]

57. Hooper, A.M.; Caulfield, J.C.; Hao, B.; Pickett, J.A.; Midega, C.A.O.; Khan, Z.R. Isolation and identification of Desmodium root exudates from drought tolerant species used as intercrops against Striga hermonthica. Phytochemistry 2015, 117, 380-387. [CrossRef]

58. Hassanali, A.; Herren, H.; Khan, Z.R.; Pickett, J.A.; Woodcock, C.M. Integrated pest management: The push-pull approach for controlling insect pests and weeds of cereals, and its potential for other agricultural systems including animal husbandry. Philos. Trans. R. Soc. B Biol. Sci. 2008, 363, 611-621. [CrossRef]

59. Khan, Z.R.; Pickett, J.A.; Hassanali, A.; Hooper, A.M.; Midega, C.A.O. Desmodium species and associated biochemical traits for controlling Striga species: Present and future prospects. Weed Res. 2008, 48, 302-306. [CrossRef]

60. Cook, B.G.; Pengelly, B.C.; Brown, S.D.; Donnelly, J.L.; Eagles, D.A.; Franco, M.A.; Hanson, J.; Mullen, B.; Partridge, I.; Peters, M.; et al. Tropical Forages: An Interactive Selection Tool; CSIRO, DPI\&F(Qld), CIAT and ILRI: Brisbane, Australia, 2005.

61. Kassie, M.; Stage, J.; Diiro, G.; Muriithi, B.; Muricho, G.; Ledermann, S.T.; Pittchar, J.; Midega, C.; Zeyaur, K. Push-pull farming system in Kenya: Implications for economic and social welfare. Land Use Policy 2018, 77, 186-198. [CrossRef]

62. Muriithi, B.W.; Menale, K.; Diiro, G.; Muricho, G. Does gender matter in the adoption of push-pull pest management and other sustainable agricultural practices? Evidence from Western Kenya. Food Secur. 2018, 10, 253-272. [CrossRef] 